\section{Effects of Timing and Intensity of Summer Pruning on Vegetative Traits of Two Southern Highbush Blueberry Cultivars}

Alisson P. Kovaleski, Jeffrey G. Williamson", Bruno Casamali, and Rebecca L. Darnell

Horticultural Sciences Department, University of Florida, 2113 Fifield Hall, Gainesville, FL 32611

Additional index words. Vaccinium corymbosum interspecific hybrid, blueberry, vegetative growth, canopy, leaf disease

\begin{abstract}
Pruning is a recommended practice for blueberry (Vaccinium spp.) production and is usually done in the summer in warm subtropical climates with long growing seasons. Summer pruning promotes healthy vegetative growth during the remainder of the growing season; however, research-based recommendations for summer pruning strategies are lacking. The objective of this study was to determine effects of summer pruning timing and intensity on vegetative growth in 'Jewel' and 'Emerald' southern highbush blueberry ( $V$. corymbosum-interspecific hybrid), two cultivars of the primary species grown in subtropical areas. To determine effects of pruning time, $\mathbf{3 0 \%}$ of the canopy was removed in June or July. To determine pruning intensity effects, either $30 \%$ or $60 \%$ of the canopy was removed in June, both followed by shoot tipping in July. Both timing and intensity treatments were compared with a non-pruned control. Lack of pruning in the first year had no negative effects on growth; however, lack of pruning for two or more seasons decreased regrowth volume and shoot length of both cultivars. By the third season, canopy regrowth volume in both cultivars decreased in the non-pruned control compared with the $30 \%$ and $60 \%$ pruning treatments and compared with the June pruning treatment. Disease infection in 'Jewel' was also increased in the nonpruned control compared with these pruning treatments. Summer pruning, regardless of timing or intensity, generally increased vigor of vegetative growth for both cultivars and decreased incidence of leaf disease in 'Jewel'.
\end{abstract}

Pruning blueberries is a recommended practice to maintain the balance between vegetative vigor and reproductive growth (Mainland, 1989; Shutak and Marucci, 1966; Williamson et al., 2004; Yarborough, 2006). Pruning improves light penetration into the canopy, adjusts leaf:fruit and shoot:root ratios (Rana et al., 2011; Ryugo, 1986), improves harvest efficiency, and reduces limb breakage (Austin, 1997; Clark and Matheny, 2010; Hrotkó, 2013). Lack of pruning, however, results in excessively tall, hard-to-pick bushes (Krewer et al., 2004; Pescie et al., 2011; Strik et al., 2003) and decreases vigor and node number in regrowth shoots (Pescie et al., 2011).

Low-chill subtropical production areas use southern highbush blueberry (SHB) cultivars and rely on high prices obtained for early-season fruit (Lyrene, 1992; Williamson and Lyrene, 2004a, 2004b). Summer pruning

Received for publication 26 Aug. 2014. Accepted for publication 12 Nov. 2014.

This work was supported by the Specialty Crops Block Grant Program, the Florida Blueberry Growers' Association, and the National Institute of Food and Agriculture.

${ }^{1}$ To whom reprint requests should be addressed; e-mail jgrw@ufl.edu. after fruit harvest is used in these areas to stimulate healthy vegetative growth for the remainder of the growing season (Patten et al., 1991; Williamson et al., 2004). Healthy foliage must be maintained in blueberry during the long growing season after fruit harvest to support optimal flower bud development and carbohydrate reserve replenishment (Lyrene, 1992, 2005; Williamson and Miller, 2002). These carbohydrates are used to supply the intensive sink demand of flowering and early fruit development the next growing season (Swain and Darnell, 2001, 2002). However, both timing and severity of summer pruning must be considered to obtain desired results (Rana et al., 2011). Early or heavy summer pruning can result in excessive regrowth, late pruning can reduce cold-hardiness, and lack of pruning can reduce the amount of regrowth (Mika and Piatkowski, 1989; Pescie et al., 2011; Williamson and Darnell, 1996).

Several studies have been done on summer pruning in blueberry (Austin, 1997; Austin and Bondari, 1989; Bañados et al., 2009; Davies, 1983; Krewer et al., 2004; Mainland, 1989; Pescie et al., 2011; Spiers et al., 2002; Williamson and Darnell, 1996); however, few studies describe the effects on vegetative traits. In Chile, early summer pruning of southern and northern highbush (V. corymbosum) blueberries increased lateral shoot number and length compared with late pruning (Bañados et al., 2009). Williamson and Darnell (1996) reported that regrowth and canopy volume of 'Sharpblue' SHB was greater when plants were pruned early after harvest compared with plants pruned later. Although severe pruning also increased regrowth compared with moderate and no pruning, regrowth volume was not enough to compensate for the loss in canopy volume resulting from pruning. Austin and Bondari (1989) found no differences in plant height measured 1 year after different pruning treatments in 'Tifblue' rabbiteye blueberry grown in Georgia, regardless of season or intensity of pruning. Similar results were found by Krewer et al. (2004) in 'Climax' rabbiteye blueberry. Mainland (1989), however, found that winter followed by summer pruning decreased rabbiteye blueberry plant size compared with winter pruning in North Carolina. In Louisiana, summer pruning of rabbiteye blueberries resulted in more and longer shoots compared with no pruning (Spiers et al., 2002). Summer pruning of blueberry appears to have more positive effects in climates with longer growing seasons (Bañados et al., 2009; Williamson and Darnell, 1996); however, proper timing and intensity of pruning remain to be determined.

Pruning reduces disease levels possibly by reducing inoculum levels, decreasing moisture retention inside the canopy, and increasing pesticide coverage (Hanson et al., 2000). Furthermore, pruning can promote vigor of the plant, increasing the productivity and survival even in the presence of disease (Smith, 2006a, 2006b; Williamson et al., 2004). Summer pruning can be useful in controlling leaf diseases such as septoria leaf spot (Septoria albopunctata) and blueberry leaf rust (Pucciniastrum vaccinii), which are emerging problems with the expansion of SHB production (Scherm et al., 2001). These leaf diseases cause marked reductions in photosynthesis (Roloff et al., 2004), fruit set, and yield (Ojiambo et al., 2006) and often cause severe defoliation (Lyrene, 1992; Ojiambo and Scherm, 2005a). However, the wounds caused by pruning can increase plant susceptibility to other diseases, most notably stem blight (Botryosphaeria dothidea, Lasiodiplodia theobromae, and Neofusicoccum ribis) (Milholland, 1972), which has been identified as the disease with the greatest economic impact in the Florida blueberry industry (Wright and Harmon, 2010). Although pruning appears to be associated with disease incidence, there are no studies that have examined the effect of timing and intensity of summer pruning on diseases in blueberry.

Most summer pruning studies on blueberries have been done in climates far different from those found in the subtropical blueberry production regions, and few studies have been done with SHB, which is expanding in acreage in the southeast United States and California, warmer regions of Argentina and Chile, and Mexico (Bañados, 2004, 2009). 
Furthermore, most studies have little information on the effects of pruning on vegetative growth or disease incidence and severity. The hypothesis tested in the current research was that summer pruning stimulates vegetative regrowth and reduces disease incidence in SHB. The objectives of this study were to determine the effects of timing and severity of summer pruning on vegetative growth, defoliation, incidence of leaf spots, and incidence and severity of stem blight in SHB.

\section{Material and Methods}

'Emerald' and 'Jewel' SHB, field-planted at the UF-IFAS Plant Science Research and Education Unit in Citra, FL, in 2006, were used in this experiment. 'Emerald' bushes are spreading to upright (Williamson et al., 2014), produce vigorous growth (Lyrene, 2008), and exhibit moderate to high resistance to leaf spots (Lyrene, 2001a) and moderate resistance to stem blight (Smith, 2006a). 'Jewel' is an upright bush with some spreading of the canes and is moderately resistant to stem blight and highly susceptible to rust leaf spots (Lyrene, 2001b; Williamson et al., 2012, 2014; Williamson and Lyrene, 2004a). The planting was on raised pine bark beds and the plants were spaced $0.9 \mathrm{~m} \times 2.7 \mathrm{~m}$ in-row and between rows, respectively. Granular fertilizer was applied at an annual rate of $239 \mathrm{~N}-35 \mathrm{P}-132 \mathrm{~K} \mathrm{~kg} \cdot \mathrm{ha}^{-1}$, evenly distributed every $20 \mathrm{~d}$ from March through October. The plants were irrigated with microsprinklers at a rate of $10.6 \mathrm{~L} / \mathrm{plant} / \mathrm{d}$ from mid-February through mid-October and $8.0 \mathrm{~L} / \mathrm{plant} / \mathrm{d}$ from mid-October through mid-February; and overhead irrigation provided frost protection. Plants were sprayed with fungicide on the following dates: 15 June 2011 with pyraclostrobin $\left(\mathrm{Cabrio}^{\circledR}\right.$; BASF Corporation, Research Triangle Park, NC) and 13 Oct. 2011 with pyraclostrobin + boscalid (Pristine $^{\circledR}$ WG; BASF Corporation); 10 Aug. and 21 Sept. 2012 with chlorothalonil (Bravo Weather Stik ${ }^{\circledR}$; Syngenta, Greensboro, NC),

Table 1. Effect of pruning time and intensity on canopy volume at the end of the growing season in 'Emerald' and 'Jewel' southern highbush blueberry.

\begin{tabular}{|c|c|c|c|c|}
\hline \multirow[b]{3}{*}{ Treatment $^{2}$} & \multicolumn{4}{|c|}{ Canopy volume $\left(\mathrm{m}^{3}\right)$} \\
\hline & \multirow[b]{2}{*}{ Emerald $^{y}$} & \multicolumn{3}{|c|}{$\begin{array}{ll}\text { Jewel } \\
\end{array}$} \\
\hline & & 2011 & 2012 & 2013 \\
\hline \multicolumn{5}{|l|}{ Timing } \\
\hline Non-pruned control & $1.42 \mathrm{a}^{\mathrm{x}}$ & $1.60 \mathrm{aB}$ & $1.69 \mathrm{aAB}$ & $1.87 \mathrm{aA}$ \\
\hline June & $1.13 \mathrm{~b}$ & $1.22 \mathrm{bB}$ & $1.30 \mathrm{bB}$ & $1.56 \mathrm{bA}$ \\
\hline July & $1.06 \mathrm{~b}$ & $1.26 \mathrm{bC}$ & $1.46 \mathrm{abB}$ & $1.80 \mathrm{abA}$ \\
\hline \multicolumn{5}{|l|}{ Intensity } \\
\hline $0 \%$ & $1.42 \mathrm{a}$ & $1.60 \mathrm{aB}$ & $1.69 \mathrm{aAB}$ & $1.87 \mathrm{aA}$ \\
\hline $30 \%$ & $1.04 \mathrm{~b}$ & $1.16 \mathrm{bC}$ & $1.34 \mathrm{bB}$ & $1.67 \mathrm{aA}$ \\
\hline $60 \%$ & $0.80 \mathrm{~b}$ & $0.75 \mathrm{cC}$ & $0.95 \mathrm{cB}$ & $1.33 \mathrm{bA}$ \\
\hline \multicolumn{5}{|l|}{ Tipping } \\
\hline Tipped & $1.04 \mathrm{a}$ & $1.16 \mathrm{aC}$ & $1.34 \mathrm{aB}$ & $1.67 \mathrm{aA}$ \\
\hline Not tipped & $1.13 \mathrm{a}$ & $1.22 \mathrm{aB}$ & $1.30 \mathrm{aB}$ & $1.56 \mathrm{aA}$ \\
\hline
\end{tabular}

${ }^{2}$ Timing, intensity, and tipping are main effects; $0 \%, 30 \%$, and $60 \%$ refer to the percentages of canopy volume removed during pruning.

'Emerald volume was averaged for 2011, 2012, and 2013 because there was no interaction between treatment and year; Jewel had a significant interaction between treatment and year.

${ }^{x}$ Means followed by the same lowercase letter within a column for each main effect or uppercase letter within a row for each cultivar are not significantly different by Tukey's honestly significant difference at $P \leq 0.05$.

31 Aug. 2012 with fenbuconazole (Indar ${ }^{\mathrm{TM}} 75$ WSP; Dow AgroSciences, Calgary, Canada) and mono and dipotassium salts of phosphorous acid (Agri-Fos ${ }^{\circledR}$; Agrichem, Loganholme, Pristine ${ }^{\circledR}$; 21 Mar. and 2 Oct. 2013 with Pristine ${ }^{\circledR}$.

Pruning treatments to assess effects of ming, intensity, and shoot tipping were To determine effects of pruning time, $30 \%$ of the canopy was removed in June (early) or July (late). To determine pruning intensity effects, either $30 \%$ (moderate) or $60 \%$ timing and intensity treatments were compared with a non-pruned control. The effect of shoot tipping was assessed by comparing vs. no tipping in July only on plant Pruning treatments as well as tipping were done mechanically, pruning the top and sides of plants with a handheld hedge trimmer, P2822 (Poulan PRO, Charlotte, NC). Tipof regrowth. In 2012 and 2013 , the treatments were pruned $5 \mathrm{~cm}$ above the cut from the previous year (followed by tipping when appropriate), therefore achieving about the complete block design (RCBD) with four plant plots (one guard plant on each side and two central data plants) and six replicaeach cultivar was evaluated independently for pruning intensity, timing, and tipping and direct comparisons between the two cultivars were node. Data were collected for three using different seasons as repeated measures. Pairwise comparisons were made to test the ain effects of timing, intensity, and tipping.

Plant canopy volume was measured after summer pruning treatments were applied the

HortScience Vol. 50(1) January 2015 first year to verify the percent of canopy removed in each pruning treatment. Subsequently, canopy volume was measured in December of each year when plants were dormant. Volume was calculated as an ellipsoid for non-pruned plants (Eq. [1]) and as a half ellipsoid for the mechanically pruned plants (Eq. [2]) as a result of different plant shapes between treatments:

$$
\begin{aligned}
V_{\text {ellipsoid }} & =\frac{4}{3} \times \pi \times \frac{H}{2} \times \frac{D_{1}}{2} \times \frac{D_{2}}{2} \\
V_{\text {half ellipsoid }} & =\frac{\left(\frac{4}{3} \times \pi \times H \times \frac{D_{1}}{2} \times \frac{D_{2}}{2}\right)}{2}
\end{aligned}
$$

Plant height $(H)$ and across-row diameter $\left(D_{1}\right)$ were measured, whereas the in-row diameter $\left(D_{2}\right)$ was assumed to be the in-row spacing because plants were growing together in a continuous hedgerow. Regrowth volume was determined by measuring canopy volume immediately after summer pruning and subtracting that from the canopy volume measured the next December, when plants were dormant. For the non-pruned control, regrowth volume was defined as the difference between the volume of plants in June and in December of each year.

After shoot growth ceased each fall, one shoot per treatment per replication was randomly collected from each cultivar to assess number of growth flushes. Five additional shoots originating from pruning cuts were randomly selected on each data plant for in situ measurements of total shoot length (including all laterals originating from that shoot) and number of lateral shoots. For non-pruned plants, the total shoot length and number of laterals of five current season's shoots were measured.

Plants were rated biweekly for leaf spot in the fall, starting in mid-November (2011), late and early October (2012 and 2013, respectively), through full defoliation in December of each year. The percentage of leaves containing at least one leaf spot (incidence) was visually estimated in the fall in all years, and the number of leaf spots per leaf (severity) was assessed in 2012 and 2013 by counting leaf spots in the five most apical fully developed leaves of one shoot per plant (Ojiambo and Scherm, 2006). Defoliation percentage was visually estimated for both cultivars. For 'Jewel', defoliation estimates were done on the same dates as leaf spot measurements, whereas 'Emerald' was rated only in December, because natural defoliation in this cultivar under Florida conditions is usually low. Estimates of defoliation were done through mid-December of all years, at which time hydrogen cyanamide $(1.5 \%)$ was applied to defoliate plants and aid in fulfilling the chilling requirement. The incidence and severity of stem blight was also determined in Dec. 2011, May 2012, and June 2012, after which no further infection of stem blight occurred. Plants with infected canes or shoots were identified and counted (incidence), and the infected parts were pruned and dried in 
a drying oven at $65{ }^{\circ} \mathrm{C}$ to obtain their dry weights (severity).

On 12 and 13 Feb. 2012, overhead irrigation was used for freeze protection. As a result of the length of the freezes and the resultant ice build-up, cane breakage occurred in some plants. Broken canes were pruned and dried in a drying oven at $65{ }^{\circ} \mathrm{C}$ to obtain dry weights.

Based on the RCBD, data were analyzed using PROC GLIMMIX on SAS 9.2 (SAS Institute Inc., Cary, NC), and pairwise comparisons of treatment means were used to compare individual treatments for main effect differences. Errors in $P$ values caused by multiple comparisons were adjusted using Tukey's honestly significant difference at $P \leq 0.05$. Whenever interactions between treatments and years [(timing, intensity, tipping) $\times$ (year)] were significant, data were analyzed within years across treatments and within treatments across years. Therefore, variables with interactions between treatment and years have averages presented for each year separately.

\section{Results}

The June and July pruning treatments resulted in $\approx 20 \%$ removal of the canopy. Canopy removal in the $30 \%$ (moderate) and $60 \%$ (heavy) pruning treatments averaged $26 \%$ and $55 \%$, respectively, for both cultivars. There were significant interactions between treatments and year for canopy volume in 'Jewel' (Table 1) and volume of regrowth (Table 2), shoot length, and number of laterals (Table 3 ) in both cultivars.

Canopy volume increased from 2011 to 2013 for all treatments in both cultivars (Table 1). Canopy volume of non-pruned 'Emerald' was significantly larger than canopy volume of June or July-pruned plants at the end of each growing season. In 'Jewel', non-pruned plants had greater canopy volumes in all years compared with June-pruned plants, whereas canopy volumes of non-pruned and July-pruned plants were similar in 2012 and 2013.

Both pruning intensities decreased canopy volume of 'Emerald' at the end of the growing season compared with the non-pruned plants (Table 1). For 'Jewel', non-pruned plants were larger than both $30 \%$ and $60 \%$ canopy removal in 2011 and 2012 but similar to $30 \%$ canopy removal in 2013. The heavy pruned plants were consistently smaller than the other pruning treatments in all 3 years. Tipping had no effect on canopy volume at the end of the growing seasons in either cultivar.

Regrowth volume of non-pruned plants (i.e., the increase in canopy volume between June and December) was greater than July-pruned plants in 2011 for both cultivars (Table 2). In 'Emerald', regrowth volume of June-pruned plants was greater compared with July-pruned plants in 2012, and it was greater than both July-pruned and the non-pruned control in 2013. For 'Jewel', there were no differences among pruning time treatments in 2012, but in 2013,
June-pruned plants had greater regrowth volume compared with the non-pruned control (Table 2). Regrowth volume of non-pruned 'Jewel' decreased significantly from 2011 to 2012 and 2013, whereas regrowth volume in the pruning treatments was either similar among years or increased with successive years. A similar pattern, although not statistically significant, was observed in 'Emerald' (Table 2).

Pruning intensity did not affect regrowth volume in 'Emerald' in 2011 or 2012 (Table

Table 2. Effect of pruning time and intensity on regrowth volume in 'Emerald' and 'Jewel' southern highbush blueberry in three growing seasons.

\begin{tabular}{|c|c|c|c|c|c|c|}
\hline \multirow[b]{3}{*}{ Treatment $^{\mathrm{y}}$} & \multicolumn{6}{|c|}{ Volume of regrowth $\left(\mathrm{m}^{3}\right)$} \\
\hline & \multicolumn{3}{|c|}{ Emerald } & \multicolumn{3}{|c|}{ Jewel } \\
\hline & 2011 & 2012 & 2013 & 2011 & 2012 & 2013 \\
\hline \multicolumn{7}{|l|}{ Timing } \\
\hline Non-pruned control & $0.21 \mathrm{aA}^{\mathrm{x}}$ & $0.14 \mathrm{abA}$ & $0.15 \mathrm{bA}$ & $0.27 \mathrm{aA}$ & $0.18 \mathrm{aB}$ & $0.13 \mathrm{bB}$ \\
\hline June & $0.17 \mathrm{abB}$ & $0.20 \mathrm{aB}$ & $0.28 \mathrm{aA}$ & $0.20 \mathrm{abA}$ & $0.22 \mathrm{aA}$ & $0.26 \mathrm{aA}$ \\
\hline July & $0.09 \mathrm{bB}$ & $0.10 \mathrm{bB}$ & $0.18 \mathrm{bA}$ & $0.12 \mathrm{bB}$ & $0.20 \mathrm{aA}$ & $0.20 \mathrm{abA}$ \\
\hline \multicolumn{7}{|l|}{ Intensity } \\
\hline $0 \%$ & $0.21 \mathrm{aA}$ & $0.14 \mathrm{aA}$ & $0.15 \mathrm{bA}$ & $0.27 \mathrm{aA}$ & $0.18 \mathrm{aB}$ & $0.13 \mathrm{bB}$ \\
\hline $30 \%$ & $0.14 \mathrm{aB}$ & $0.11 \mathrm{aB}$ & $0.21 \mathrm{aA}$ & $0.16 \mathrm{bB}$ & $0.22 \mathrm{aAB}$ & $0.27 \mathrm{aA}$ \\
\hline $60 \%$ & $0.16 \mathrm{aA}$ & $0.17 \mathrm{aA}$ & $0.21 \mathrm{aA}$ & $0.17 \mathrm{bB}$ & $0.25 \mathrm{aAB}$ & $0.32 \mathrm{aA}$ \\
\hline \multicolumn{7}{|l|}{ Tipping } \\
\hline Tipped & $0.14 \mathrm{aB}$ & $0.11 \mathrm{bB}$ & $0.21 \mathrm{bA}$ & $0.16 \mathrm{aB}$ & $0.22 \mathrm{aAB}$ & $0.27 \mathrm{aA}$ \\
\hline Not tipped & $0.17 \mathrm{aB}$ & $0.20 \mathrm{aB}$ & $0.28 \mathrm{aA}$ & $0.20 \mathrm{aA}$ & $0.22 \mathrm{aA}$ & $0.26 \mathrm{aA}$ \\
\hline
\end{tabular}

${ }^{\mathrm{z}}$ Regrowth $=($ volume at the end of growing season $)-($ volume immediately after pruning, or June for the non-pruned control) in each year.

'Timing, intensity, and tipping are main effects; $0 \%, 30 \%$, and $60 \%$ refer to the percentages of canopy volume removed during pruning.

${ }^{\mathrm{x}}$ Means followed by the same lowercase letter within a column for each main effect or uppercase letter within a row for each cultivar are not significantly different by Tukey's honestly significant difference at $P \leq 0.05$.

Table 3. Effect of pruning time and intensity on regrowth lateral shoot length and number of laterals per shoot in 'Emerald' and 'Jewel' southern highbush blueberry.

\begin{tabular}{|c|c|c|c|c|c|c|}
\hline \multirow[b]{2}{*}{ Treatment $^{\mathrm{z}}$} & \multicolumn{3}{|c|}{ Shoot length $(\mathrm{cm})$} & \multicolumn{3}{|c|}{ Lateral no./shoot } \\
\hline & 2011 & 2012 & 2013 & 2011 & 2012 & 2013 \\
\hline \multicolumn{7}{|l|}{ Emerald } \\
\hline \multicolumn{7}{|l|}{ Timing } \\
\hline Non-pruned control ${ }^{\mathrm{y}}$ & $59.0 \mathrm{aA}^{\mathrm{x}}$ & $33.3 \mathrm{aB}$ & $24.8 \mathrm{aB}$ & $3.2 \mathrm{aA}$ & $1.5 \mathrm{aB}$ & $1.2 \mathrm{aB}$ \\
\hline June & $26.4 \mathrm{bAB}$ & $31.3 \mathrm{aA}$ & $20.9 \mathrm{aB}$ & $1.2 \mathrm{bB}$ & $1.4 \mathrm{aA}$ & $1.2 \mathrm{aB}$ \\
\hline July & $18.7 \mathrm{bA}$ & $13.9 \mathrm{bB}$ & $12.0 \mathrm{bB}$ & $1.5 \mathrm{bA}$ & $1.1 \mathrm{aA}$ & $1.0 \mathrm{aA}$ \\
\hline \multicolumn{7}{|l|}{ Intensity } \\
\hline $0 \%$ & $59.0 \mathrm{aA}$ & $33.3 \mathrm{aB}$ & $24.8 \mathrm{abB}$ & $3.2 \mathrm{aA}$ & $1.5 \mathrm{bB}$ & $1.2 \mathrm{bB}$ \\
\hline $30 \%$ & $19.8 \mathrm{cA}$ & $22.9 \mathrm{aA}$ & $20.1 \mathrm{bA}$ & $1.4 \mathrm{bA}$ & $1.8 \mathrm{abA}$ & $1.4 \mathrm{bA}$ \\
\hline $60 \%$ & $40.9 \mathrm{bA}$ & $34.3 \mathrm{aAB}$ & $28.3 \mathrm{aB}$ & $2.0 \mathrm{bAB}$ & $2.3 \mathrm{aA}$ & $1.7 \mathrm{aB}$ \\
\hline \multicolumn{7}{|l|}{ Tipping } \\
\hline Tipped & $19.8 \mathrm{aA}$ & $22.9 \mathrm{aA}$ & $20.1 \mathrm{aA}$ & $1.4 \mathrm{aA}$ & $1.8 \mathrm{aA}$ & $1.4 \mathrm{aA}$ \\
\hline Not tipped & $26.4 \mathrm{aAB}$ & $31.3 \mathrm{aA}$ & $20.9 \mathrm{aB}$ & $1.2 \mathrm{aB}$ & $1.4 \mathrm{aA}$ & $1.2 \mathrm{aB}$ \\
\hline \multicolumn{7}{|l|}{ Jewel } \\
\hline \multicolumn{7}{|l|}{ Timing } \\
\hline Non-pruned control & $63.0 \mathrm{aA}$ & $54.0 \mathrm{aA}$ & $23.7 \mathrm{aB}$ & $5.8 \mathrm{aA}$ & $2.5 \mathrm{aB}$ & $1.3 \mathrm{aB}$ \\
\hline June & $31.4 \mathrm{bAB}$ & $39.4 \mathrm{abA}$ & $26.3 \mathrm{aB}$ & $1.7 \mathrm{bA}$ & $2.3 \mathrm{aA}$ & $1.8 \mathrm{aA}$ \\
\hline July & $23.9 \mathrm{bA}$ & $25.0 \mathrm{bA}$ & $21.2 \mathrm{aA}$ & $1.9 \mathrm{bA}$ & $1.8 \mathrm{aA}$ & $1.4 \mathrm{aA}$ \\
\hline \multicolumn{7}{|l|}{ Intensity } \\
\hline $0 \%$ & $63.0 \mathrm{aA}$ & $54.0 \mathrm{aA}$ & $23.7 \mathrm{bB}$ & $5.8 \mathrm{aA}$ & $2.5 \mathrm{bB}$ & $1.3 \mathrm{cB}$ \\
\hline $30 \%$ & $31.8 \mathrm{bA}$ & $40.0 \mathrm{aA}$ & $29.8 \mathrm{bA}$ & $2.6 \mathrm{bA}$ & $3.1 \mathrm{abA}$ & $2.8 \mathrm{bA}$ \\
\hline $60 \%$ & $49.7 \mathrm{aA}$ & $52.3 \mathrm{aA}$ & $49.9 \mathrm{aA}$ & $3.6 \mathrm{bA}$ & $3.8 \mathrm{aA}$ & $4.0 \mathrm{aA}$ \\
\hline \multicolumn{7}{|l|}{ Tipping } \\
\hline Tipped & $31.8 \mathrm{aA}$ & $40.0 \mathrm{aA}$ & $29.8 \mathrm{aA}$ & $2.6 \mathrm{aA}$ & $3.1 \mathrm{aA}$ & $2.8 \mathrm{aA}$ \\
\hline Not tipped & $31.4 \mathrm{aAB}$ & $39.4 \mathrm{aA}$ & $26.3 \mathrm{aB}$ & $1.7 \mathrm{aA}$ & $2.3 \mathrm{aA}$ & $1.8 \mathrm{aA}$ \\
\hline
\end{tabular}

zTiming, intensity, and tipping are main effects; $0 \%, 30 \%$, and $60 \%$ refer to the percentages of canopy volume removed during pruning.

${ }^{y}$ Shoot length and number of laterals in non-pruned control plants were measured in shoots growing from the beginning of the growth season.

${ }^{\mathrm{x}}$ Means followed by the same lowercase letter within a column for each main effect and cultivar or uppercase letter within a row for each variable are not significantly different by Tukey's honestly significant difference at $P \leq 0.05$. 
in 2011 in both cultivars (Table 3). In 2012 and 2013, both the non-pruned control and June-pruned plants had longer shoots compared with July-pruned plants of 'Emerald'. In 'Jewel', July pruning decreased shoot length compared with the non-pruned control 2012, but there were no differences in shoot length among pruning time treatments in 2013. The effect of pruning time on the number of laterals was similar in both cultivars (Table 3 ). June and July pruning reduced the number of laterals in 2011, but there were no differences among treatments in 2012 or 2013. Similar to the reduction in shoot length, late pruning (July) also reduced the number of regrowth flushes in 'Emerald' compared with the early pruning treatment in 2011 and 2012 (data not shown). Late pruning also tended to reduce the number of regrowth flushes in 'Jewel'.

Moderate (30\%) and heavy (60\%) pruning intensities reduced shoot length of regrowth in 'Emerald' compared with the non-pruned control in 2011 (Table 3). In 2012 there were no differences among treatments, and in 2013, the heavy pruning resulted in increased regrowth compared with the moderate pruning. For 'Jewel', both heavy and no pruning resulted in greater regrowth compared with moderate pruning in 2011. In 2012, there were no differences among intensities, and in 2013, heavy pruning had greater regrowth compared with both non-pruned and moderate pruning. The effect of pruning intensities on number of laterals was similar in both cultivars. In 2011, non-pruned plants produced more laterals compared with $30 \%$ and $60 \%$ pruning. However, heavy pruning resulted in an increased number of laterals compared with non-pruned in 2012 and compared with non-pruned and moderate pruning in 2013. Tipping had no effect on shoot length or number of laterals in either cultivar.

There were no differences among treatments for cane breakage resulting from freeze protection in 'Emerald', whereas only intensity affected cane breakage for 'Jewel'. The non-pruned 'Jewel' plants had increased cane breakage compared with both $30 \%$ and $60 \%$ pruning treatments (data not shown).

'Jewel' was severely affected by leaf spots, visually identified as blueberry leaf rust, especially in 2012 and 2013 (Table 4); however, July pruning reduced the incidence of leaf spots through early Nov. 2012 compared with the non-pruned control. In 2013, both June and July pruning reduced the incidence of leaf spots through mid-November compared with the non-pruned control. Non-pruned plants also exhibited greater leaf spot severity (as measured by average number of leaf spots per leaf) compared with June and July pruning treatments (Table 5). No significant leaf spot infections were observed in 'Emerald' in any of the growing seasons.

In 'Jewel', both pruning intensities generally had a lower incidence of leaf spots through mid-November compared with the non-pruned control (Table 4). However, intensity of pruning had no effect on leaf spot severity (Table 5), whereas tipping had no effect on either incidence or severity of leaf spots. Stem blight was not observed in

Table 4. Effect of pruning time and intensity on incidence of leaf spots in 'Jewel' southern highbush blueberry.

\begin{tabular}{|c|c|c|c|c|c|c|}
\hline \multirow{2}{*}{$\begin{array}{l}\text { Treatment }^{z} \\
\text { Timing }\end{array}$} & \multicolumn{6}{|c|}{ Leaves containing at least one leaf spot (\%) } \\
\hline & & & & & & \\
\hline 2011 & $-^{y}$ & - & - & 17 Nov. & 1 Dec. & 21 Dec. \\
\hline Non-pruned control & - & - & - & $70.0 \mathrm{a}^{\mathrm{x}}$ & $70.0 \mathrm{a}$ & $56.7 \mathrm{a}$ \\
\hline June & - & - & - & $43.3 \mathrm{a}$ & $40.0 \mathrm{a}$ & $50.0 \mathrm{a}$ \\
\hline July & - & - & - & $66.7 \mathrm{a}$ & $73.3 \mathrm{a}$ & $66.7 \mathrm{a}$ \\
\hline 2012 & - & - & 25 Oct. & 8 Nov. & 23 Nov. & 11 Dec. \\
\hline Non-pruned control & - & - & $38.3 \mathrm{a}$ & $81.7 \mathrm{a}$ & $88.3 \mathrm{a}$ & $97.5 \mathrm{a}$ \\
\hline June & - & - & $35.0 \mathrm{a}$ & $61.7 \mathrm{ab}$ & $83.3 \mathrm{a}$ & $95.0 \mathrm{a}$ \\
\hline July & - & - & $15.8 \mathrm{~b}$ & $41.7 \mathrm{~b}$ & $78.3 \mathrm{a}$ & $94.2 \mathrm{a}$ \\
\hline 2013 & 3 Oct. & 17 Oct. & 31 Oct. & 14 Nov. & 29 Nov. & 12 Dec. \\
\hline Non-pruned control & $63.3 \mathrm{a}$ & $95.0 \mathrm{a}$ & $99.2 \mathrm{a}$ & $100.0 \mathrm{a}$ & $100.0 \mathrm{a}$ & $100.0 \mathrm{a}$ \\
\hline June & $24.2 \mathrm{~b}$ & $68.3 \mathrm{~b}$ & $88.3 \mathrm{~b}$ & $91.7 \mathrm{~b}$ & $100.0 \mathrm{a}$ & $100.0 \mathrm{a}$ \\
\hline July & $32.5 \mathrm{~b}$ & $73.3 \mathrm{ab}$ & $90.0 \mathrm{~b}$ & $94.2 \mathrm{~b}$ & $100.0 \mathrm{a}$ & $100.0 \mathrm{a}$ \\
\hline \multicolumn{7}{|l|}{ Intensity } \\
\hline 2011 & $\mathrm{y}^{\mathrm{y}}$ & - & - & 17 Nov. & 1 Dec. & 21 Dec. \\
\hline $0 \%$ & - & - & - & $70.0 \mathrm{a}^{\mathrm{x}}$ & $70.0 \mathrm{a}$ & $56.7 \mathrm{a}$ \\
\hline $30 \%$ & - & - & - & $36.7 \mathrm{~b}$ & $40.0 \mathrm{a}$ & $63.3 \mathrm{a}$ \\
\hline $60 \%$ & - & - & - & $36.7 \mathrm{~b}$ & $43.3 \mathrm{a}$ & $83.3 \mathrm{a}$ \\
\hline 2012 & - & - & 25 Oct. & 8 Nov. & 23 Nov. & 11 Dec. \\
\hline $0 \%$ & - & - & $38.3 \mathrm{a}$ & $81.7 \mathrm{a}$ & $88.3 \mathrm{a}$ & $97.5 \mathrm{a}$ \\
\hline $30 \%$ & - & - & $26.7 \mathrm{ab}$ & $53.3 \mathrm{~b}$ & $81.7 \mathrm{ab}$ & $96.7 \mathrm{a}$ \\
\hline $60 \%$ & - & - & $15.0 \mathrm{~b}$ & $53.3 \mathrm{~b}$ & $73.3 \mathrm{~b}$ & $100.0 \mathrm{a}$ \\
\hline 2013 & 3 Oct. & 17 Oct. & 31 Oct. & 14 Nov. & 29 Nov. & 12 Dec. \\
\hline $0 \%$ & $63.3 \mathrm{a}$ & $95.0 \mathrm{a}$ & $99.2 \mathrm{a}$ & $100.0 \mathrm{a}$ & $100.0 \mathrm{a}$ & $100.0 \mathrm{a}$ \\
\hline $30 \%$ & $26.7 \mathrm{~b}$ & $78.3 \mathrm{ab}$ & $90.8 \mathrm{~b}$ & $95.0 \mathrm{~b}$ & $100.0 \mathrm{a}$ & $100.0 \mathrm{a}$ \\
\hline $60 \%$ & $23.3 \mathrm{~b}$ & $66.7 \mathrm{~b}$ & $86.7 \mathrm{~b}$ & $92.5 \mathrm{c}$ & $100.0 \mathrm{a}$ & $100.0 \mathrm{a}$ \\
\hline \multicolumn{7}{|l|}{ Tipping } \\
\hline 2011 & - & - & - & 17 Nov. & 1 Dec. & 21 Dec. \\
\hline Tipped & - & - & - & $36.7 \mathrm{a}$ & $40.0 \mathrm{a}$ & $63.3 \mathrm{a}$ \\
\hline Not tipped & - & - & - & $43.3 \mathrm{a}$ & $40.0 \mathrm{a}$ & $50.0 \mathrm{a}$ \\
\hline 2012 & - & - & 25 Oct. & 8 Nov. & 23 Nov. & 11 Dec. \\
\hline Tipped & - & - & $26.7 \mathrm{a}$ & $53.3 \mathrm{a}$ & $81.7 \mathrm{a}$ & $96.7 \mathrm{a}$ \\
\hline Not tipped & - & - & $35.0 \mathrm{a}$ & $61.7 \mathrm{a}$ & $83.3 \mathrm{a}$ & $95.0 \mathrm{a}$ \\
\hline 2013 & 3 Oct. & 17 Oct. & 31 Oct. & 14 Nov. & 29 Nov. & 12 Dec. \\
\hline Tipped & $26.7 \mathrm{a}$ & $78.3 \mathrm{a}$ & $90.8 \mathrm{a}$ & $95.0 \mathrm{a}$ & $100.0 \mathrm{a}$ & $100.0 \mathrm{a}$ \\
\hline Not tipped & $24.2 \mathrm{a}$ & $68.3 \mathrm{a}$ & $88.3 \mathrm{a}$ & $91.7 \mathrm{a}$ & $100.0 \mathrm{a}$ & $100.0 \mathrm{a}$ \\
\hline
\end{tabular}

${ }^{2}$ Timing, intensity, and tipping are main effects; $0 \%, 30 \%$, and $60 \%$ refer to the percentages of canopy volume removed during pruning.

${ }^{y}$ Data were collected on three dates in 2011, four dates in 2012, and six dates in 2013.

${ }^{x}$ Means followed by the same letter within a column within each year for each main effect are not significantly different by Tukey's honestly significant difference at $P \leq 0.05$.

'Jewel' over the three seasons. In 'Emerald', $8 \%$ to $33 \%$ of the plants exhibited stem blight, but there were no differences among timings, intensities, or tipping for incidence or severity (data not shown).

In general, June- and July-pruned 'Jewel' defoliated later and to a lesser extent compared with the non-pruned control (Table 5). Similarly, $30 \%$ and $60 \%$ canopy removal delayed defoliation compared with the non-pruned control. Tipping had no effect on defoliation in 'Jewel'. Defoliation was relatively low for 'Emerald' by the end of the season in all years (data not shown), and there were no differences among treatments in 2011 or 2013. In 2012, only the $30 \%$ pruning treatment had greater defoliation than the non-pruned control.

\section{Discussion}

Although summer pruning is used to stimulate healthy vegetative growth in blueberries, this is the first report on effects of timing and intensity of summer pruning on vegetative growth and disease incidence and severity in SHB.

The lack of difference in canopy volume starting in 2012 between July-pruned and non-pruned 'Jewel' plants was a reflection of both the increase in regrowth volume from 2011 to 2012 in the July pruning treatment and a reduction in the regrowth in the non-pruned plants. Although the July pruning resulted in decreased shoot length compared with no pruning in 2011 and 2012, pruning likely increased the number of growing points, leading to regrowth volume and canopy volume comparable to non-pruned plants starting in 2012. Little or no differences in canopy and regrowth volume were seen between June and July pruning treatments in 'Jewel' probably as a result of the long growing season. In 'Emerald', differences in regrowth volume between June and July 
Table 5. Effect of pruning time and intensity on defoliation and leaf spot severity in 'Jewel' southern highbush blueberry.

\begin{tabular}{|c|c|c|c|c|c|c|c|}
\hline \multirow[b]{2}{*}{ Treatment $^{z}$} & \multirow[b]{2}{*}{$\begin{array}{c}\text { Leaf } \\
\text { spot no. }\end{array}$} & \multicolumn{6}{|c|}{ Defoliation (\%) } \\
\hline & & $\begin{array}{l}\text { Early } \\
\text { Oct. }^{\mathrm{x}}\end{array}$ & Mid-Oct. & $\begin{array}{l}\text { Late } \\
\text { Oct. }\end{array}$ & Mid-Nov. & $\begin{array}{l}\text { Late } \\
\text { Nov. }\end{array}$ & Mid-Dec. \\
\hline \multicolumn{8}{|l|}{ Timing } \\
\hline Non-pruned control & $19.0 \mathrm{a}^{\mathrm{w}}$ & $27.5 \mathrm{a}$ & $47.5 \mathrm{a}$ & $42.1 \mathrm{a}$ & $47.5 \mathrm{a}$ & $55.0 \mathrm{a}$ & $66.9 \mathrm{a}$ \\
\hline June & $13.1 \mathrm{~b}$ & $7.5 \mathrm{~b}$ & $14.2 \mathrm{~b}$ & $20.4 \mathrm{~b}$ & $19.2 \mathrm{~b}$ & $26.7 \mathrm{~b}$ & $51.1 \mathrm{~b}$ \\
\hline July & $12.5 \mathrm{~b}$ & $11.7 \mathrm{~b}$ & $24.2 \mathrm{ab}$ & $21.3 \mathrm{~b}$ & $25.8 \mathrm{~b}$ & $35.0 \mathrm{~b}$ & $61.7 \mathrm{ab}$ \\
\hline \multicolumn{8}{|l|}{ Intensity } \\
\hline $0 \%$ & $19.0 \mathrm{a}$ & $27.5 \mathrm{a}$ & $47.5 \mathrm{a}$ & $42.1 \mathrm{a}$ & $47.5 \mathrm{a}$ & $55.0 \mathrm{a}$ & 66.9 a \\
\hline $30 \%$ & $14.0 \mathrm{a}$ & $7.5 \mathrm{~b}$ & $20.0 \mathrm{~b}$ & $20.8 \mathrm{~b}$ & $22.5 \mathrm{~b}$ & $28.3 \mathrm{~b}$ & $57.2 \mathrm{ab}$ \\
\hline $60 \%$ & $16.7 \mathrm{a}$ & $6.7 \mathrm{~b}$ & $13.3 \mathrm{~b}$ & $12.9 \mathrm{~b}$ & $13.8 \mathrm{~b}$ & $18.6 \mathrm{~b}$ & $53.3 \mathrm{~b}$ \\
\hline \multicolumn{8}{|l|}{ Tipping } \\
\hline Tipped & $14.0 \mathrm{a}$ & $7.5 \mathrm{a}$ & $20.0 \mathrm{a}$ & $20.8 \mathrm{a}$ & $22.5 \mathrm{a}$ & $28.3 \mathrm{a}$ & $57.2 \mathrm{a}$ \\
\hline Not tipped & $13.1 \mathrm{a}$ & $7.5 \mathrm{a}$ & $14.2 \mathrm{a}$ & $20.4 \mathrm{a}$ & $19.2 \mathrm{a}$ & $26.7 \mathrm{a}$ & $51.1 \mathrm{a}$ \\
\hline
\end{tabular}

${ }^{\mathrm{z}}$ Timing, intensity, and tipping are main effects; $0 \%, 30 \%$, and $60 \%$ refer to the percentages of canopy volume removed during pruning.

${ }^{\mathrm{y}}$ Average number of leaf spots were counted in five fully expanded leaves in one shoot per data plant. Data were collected on 8 Nov., 23 Nov., and 11 Dec. 2012 and 14 Nov., 29 Nov., and 12 Dec. 2013 and averaged overall dates since there were no interactions between treatment, date and year.

${ }^{\mathrm{x}}$ Early October refers to data collected on 3 Oct. 2013; Mid-Oct. refers to data collected on 17 Oct. 2013 Late Oct. refers to data collected on 25 Oct. 2012 and 31 Oct. 2013; Mid-Nov. refers to data collected on 17 Nov. 2011, 8 Nov. 2012, and 14 Nov. 2013; Late Nov. refers to data collected on 1 Dec. 2011, 23 Nov. 2012, and 29 Nov. 2012; Mid-Dec. refers to data collected on 21 Dec. 2011, 11 Dec. 2012, and 12 Dec. 2013. Data were averaged within each date for 2011, 2012, and 2013 because there were no interactions between treatment and year.

${ }^{\text {w} M e a n s ~ f o l l o w e d ~ b y ~ t h e ~ s a m e ~ l e t t e r ~ w i t h i n ~ a ~ c o l u m n ~ f o r ~ e a c h ~ m a i n ~ e f f e c t ~ a r e ~ n o t ~ s i g n i f i c a n t l y ~ d i f f e r e n t ~ b y ~}$ Tukey's honestly significant difference at $P \leq 0.05$.

pruning treatments were probably the result of earlier cessation of shoot growth and formation of flower buds in this cultivar compared with 'Jewel' (Bañados and Strik, 2006; Kovaleski et al., 2015). Thus, unlike the June pruning treatment, pruning 'Emerald' in July would not have allowed sufficient time for shoot regrowth to occur. Williamson and Darnell (1996), however, found a decreased plant height and canopy volume in late-pruned compared with early-pruned 'Sharpblue'. Similarly, Bañados et al. (2009) found a reduction in growth and lateral branching in both southern and northern highbush blueberry when pruned 2 to 3 months after harvest compared with pruning soon after harvest. In both studies, however, the late summer pruning was later in the season than the late pruning in our study and would therefore reduce the time for plants to regrow before dormancy.

The lack of differences in canopy volume between 30\% and non-pruned 'Jewel' plants in 2013 suggests a compensatory growth, where pruning promoted sufficient regrowth to overcome the pruned volume. The lack of difference in canopy volume of 'Emerald' between the $30 \%$ and $60 \%$ pruning treatments suggests a similar compensatory growth response. In the case of 'Emerald', however, pruned plants did not attain the same canopy volume as non-pruned plants, which is similar to response found by Williamson and Darnell (1996). This difference in cultivar response to pruning intensity may be the result of plant architecture differences, because 'Emerald' has shorter regrowth shoots compared with 'Jewel', resulting in a more pronounced dwarfing effect from pruning.

Regrowth volume of non-pruned 'Jewel' was greater compared with $30 \%$ and $60 \%$ pruned, which may have contributed to greater ice build-up during freeze protection, resulting in increased cane breakage compared with the other treatments. This effect was not observed in 'Emerald', possibly because its architecture is less upright compared with 'Jewel' (Lyrene, 2001b, 2008). However, the significant reduction in regrowth volume of non-pruned 'Jewel' from 2011 through 2013, and a similar, although not statistically significant trend observed in 'Emerald' $(P=0.06)$, suggests that lack of pruning reduces vegetative vigor in SHB over time. This effect was also seen in the reduction in the number of growth flushes in the regrowth of 'Jewel' non-pruned plants compared with all pruning treatments from 2011 to 2013 (data not shown). The same effect was described in a winter pruning study with two highbush blueberry cultivars by Strik et al. (2003), who suggested that the decreased regrowth resulting from the lack of pruning may have a negative impact on berry weight, picking efficiency, and yield. The reduction in lateral shoot length and number from 2011 to 2013 in the non-pruned plants follows the canopy regrowth volume trend and further supports the loss of vigor resulting from no pruning.

The decrease in shoot length caused by heavy $(60 \%)$ pruning in 'Emerald' from 2011 to 2013 may indicate a loss of vigor in this treatment, possibly as a result of carbohydrate depletion resulting from excessively heavy pruning in all years (McFadyen et al., 2011). However, the decrease in shoot length in 'Emerald' was not reflected in a decrease in regrowth volume. This is probably because shoot length was a cumulative measurement of the length of shoots and all laterals, and the reduction in the number of laterals would decrease shoot length without affecting volume.
This effect of $60 \%$ pruning was not observed in 'Jewel', possibly because the plants were larger and therefore contained more reserves. However, continued heavy pruning of this cultivar may eventually result in similar decreases in shoot length.

Although shoot length decreased ('Emerald') or remained the same ('Jewel') in the $60 \%$ pruning treatment over the 3-year period, shoots in this treatment were as long or longer compared with the $30 \%$ and $0 \%$ pruning treatments in both cultivars. A similar effect was observed by Spiers et al. (2002), where regrowth shoot number and length of 'Climax' rabbiteye blueberry were significantly greater in heavily pruned compared with non-pruned plants. Heavy pruning of 'Sharpblue' SHB also increased regrowth shoot length compared with moderate and no pruning (Williamson and Darnell, 1996). Although these studies only evaluated or described the pruning effects in the first year after pruning treatments, it is possible that heavy pruning may promote continuously vigorous shoot regrowth over several years.

In 2013, the incidence of leaf spots in 'Jewel' was remarkably high for all treatments, averaging 91\% across all treatments by 31 Oct., much earlier than in the previous 2 years. The incidence of leaf spots in Dec. 2012 was also considerably higher than in 2011. This could be a result of the increased rainfall in the summer months of 2012 and 2013 and less fungicide applications (in 2013), which may have contributed to the spread of leaf spot diseases during summer regrowth (Scherm et al., 2007; Williamson and Miller, 2002). Non-pruned 'Jewel' plants consistently had the highest percentage of leaves containing leaf spots in all years, likely because older infected leaves were not removed through summer pruning. The high incidence of leaf spots in this treatment likely led to the increased leaf defoliation (Ojiambo et al., 2006; Ojiambo and Scherm, 2005a), which would reduce photosynthesis of the non-pruned plants during the fall, as described by Roloff et al. (2004), and contribute to the loss of vigor in these plants over the years. Occasional decreases in the incidence of leaf spots such as from 1 Dec. to 21 Dec. 2011 in the non-pruned control and July pruning treatments are likely the result of defoliation of severely affected leaves, as found by Ojiambo and Scherm (2005b). The low defoliation seen in 'Emerald' is typical, probably as a result of the resistance to leaf diseases (Lyrene, 2001a), which aids in maintaining healthier foliage through the fall.

Lack of pruning in the first year had no severe negative effects on the growth of the cultivars analyzed, whereas tipping had no effect over the 3 years, possibly because the evaluation of tipping (i.e., tipping vs. no tipping) was only done at the $30 \%$ pruning intensity. However, lack of pruning for two or more seasons decreased vegetative vigor compared with pruning treatments as measured by regrowth volume, which may decrease flower bud formation and yield (Lyrene, 2005). Lack of pruning also resulted 
in increased early-season incidence and severity of leaf rust and increased cane breakage from freeze protection in 'Jewel'. Data indicate that summer pruning, regardless of timing or intensity, is beneficial for the vegetative growth of SHB. Moderate $(30 \%)$ and early pruning increased vegetative regrowth over time for both cultivars, and reduced cane breakage and disease infection for 'Jewel'.

\section{Literature Cited}

Austin, M.E. 1997. Winter vs. summer half-hedging of 'Tifblue' rabbiteye blueberry plants. J. Small Fruit \& Viticul. 5:29-46.

Austin, M.E. and K. Bondari. 1989. Fertilizer rate and hedging intensity influences on the yield and fruit size of rabbiteye blueberry, cultivar Tifblue. Fert. Res. 18:233-243.

Bañados, M.P. 2004. Blueberry production in South America. Acta Hort. 715:165-172.

Bañados, M.P. 2009. Expanding blueberry production into non-traditional production areas: Northern Chile and Argentina, Mexico and Spain. Acta Hort. 810:439-444.

Bañados, M.P. and B. Strik. 2006. Manipulation of the annual growth cycle of blueberry using photoperiod. Acta Hort. 715:65-71.

Bañados, P., P. Uribe, and D. Donnay. 2009. The effect of summer pruning date in 'Star', 'O'Neal' and 'Elliot'. Acta Hort. 810:501-507.

Clark, J.R. and N. Matheny. 2010. The research foundation to tree pruning: A review of the literature. Arboricult. and Urban For. 36:110-120.

Davies, F.S. 1983. Pruning, yield and morphology of 3 rabbiteye blueberry cultivars in Florida. Proc. Fla. State Hort. Soc. 96:192-195.

Hanson, E., J. Hancock, D.C. Ramsdell, A. Schilder, G. Vanee, and R. Ledebuhr. 2000. Sprayer type and pruning affect the incidence of blueberry fruit rots. HortScience 35:235238.

Hrotkó, K. 2013. Development in fruit trees production systems. AgroLife Sci. J. 2:28-35.

Kovaleski, A.P., J.G. Williamson, J.W. Olmstead, and R.L. Darnell. 2015. Inflorescence bud initiation, development, and bloom in two southern highbush blueberry cultivars. J. Amer. Soc. Hort. Sci. (in press)

Krewer, G., D. Stanaland, S. NeSmith, and B. Mullinix. 2004. Post-harvest hedging and pruning of three year pruning trial on 'Climax' and 'Tifblue' rabbiteye blueberry. Small Fruits Rev. 3:203-212.

Lyrene, P.M. 1992. Early defoliation reduces flower bud counts on rabbiteye blueberry. HortScience 27:783-785.

Lyrene, P.M. 2001a. Blueberry plant called 'Emerald'. U.S. Patent No. PP12,165. 23 Oct. 2001.

Lyrene, P.M. 2001b. Blueberry plant named 'Jewel'. U.S. Patent No. PP11,807. 13 Mar. 2001.

Lyrene, P.M. 2005. Breeding low-chill blueberries and peaches for subtropical areas. HortScience 40:1947-1949.
Lyrene, P.M. 2008. 'Emerald' southern highbush blueberry. HortScience 43:1606-1607.

Mainland, C.M. 1989. Managing the growth and fruiting of rabbiteye (Vaccinium ashei Reade) blueberries with pruning and growth regulators. Acta Hort. 241:195-200.

McFadyen, L.M., D. Robertson, M. Sedgley, P. Kristiansen, and T. Olesen. 2011. Post-pruning shoot growth increases fruit abscission and reduces stem carbohydrates and yield in macadamia. Ann. Bot. (Lond.) 107:993-1001.

Mika, A. and M. Piatkowski. 1989. Controlling tree size in dense plantings by winter and summer pruning. Acta Hort. 243:95-102.

Milholland, R.D. 1972. Histopathology and pathogenicity of Botryosphaeria dothidea on blueberry stems. Phytopathology 62:654-660.

Ojiambo, P.S. and H. Scherm. 2005a. Survival analysis of time to abscission of blueberry leaves affected by septoria leaf spot. Phytopathology 95:108-113.

Ojiambo, P.S. and H. Scherm. 2005b. Temporal progress of septoria leaf spot on rabbiteye blueberry (Vaccinium ashei). Plant Dis. 89: 1090-1096.

Ojiambo, P.S. and H. Scherm. 2006. Optimum sample size for determining disease severity and defoliation associated with septoria leaf spot of blueberry. Plant Dis. 90:1209-1213.

Ojiambo, P.S., H. Scherm, and P.M. Brannen. 2006. Septoria leaf spot reduces flower bud set and yield potential of rabbiteye and southern highbush blueberries. Plant Dis. 90:51-57.

Patten, K., E. Neuendorff, G. Nimr, J.R. Clark, and G. Fernandez. 1991. Cold injury of southern blueberries as a function of germplasm and season of flower bud development. HortScience 26:18-20.

Pescie, M., M. Borda, P. Fedyszak, and C. López. 2011. Efecto del momento y tipo de poda sobre el rendimiento y calidade del fruto en arándano altos del sur (Vaccinium corymbosum) var. O'Neal en la provincia de Buenos Aires. Rev. de Invest. Agrop. 37:268-274.

Rana, V.S., J. Basar, and A.S. Rehalia. 2011. Effect of time and severity of summer pruning on the vine characteristics, fruit yield and quality of kiwifruit. Acta Hort. 913:393-400.

Roloff, I., H. Scherm, and M.W. van Iersel. 2004. Photosynthesis of blueberry leaves as affected by septoria leaf spot and abiotic leaf damage. Plant Dis. 88:397-401.

Ryugo, K. 1986. Promotion and inhibition of flower initiation and fruit set by plant manipulation and hormones, a review. Acta Hort. 179:301-307.

Scherm, H., D.S. NeSmith, D.L. Horton, and G. Krewer. 2001. A survey of horticultural and pest management practices of the Georgia blueberry industry. Small Fruits Rev. 1:17-28.

Scherm, H., A.T. Savelle, P.M. Brannen, and G. Krewer. 2007. Occurrence and prevalence of foliar diseases on blueberry in Georgia. Plant Health Prog. 6 June 2014. <http://www. plantmanagementnetwork.org/pub/php/research/ 2008/blueberry/>.
Shutak, V.G. and P.E. Marucci. 1966. Plant and fruit development. In: Eck, P. and N.F. Childers (eds.). Blueberry culture. Rutgers Univ. Press, New Brunswick, NJ.

Smith, B.J. 2006a. Phytophthora root rot and Botryosphaeria stem blight: Important diseases of southern highbush blueberries in the Southern United States. Acta Hort. 715:473-479.

Smith, B.J. 2006b. Susceptibility of southern highbush blueberry cultivars to Botryosphaeria stem blight. Small Fruits Rev. 3:193-201.

Spiers, J.M., J.H. Braswell, and R.J. Constantin. 2002. Effects of pruning on 'Climax' rabbiteye blueberry. Acta Hort. 574:233-237.

Strik, B., G. Buller, and E. Hellman. 2003. Pruning severity affects yield, berry weight, and hand harvest efficiency of highbush blueberry. HortScience 38:196-199.

Swain, P.A.W. and R.L. Darnell. 2001. Differences in phenology and reserve carbohydrate concentrations between dormant and nondormant production systems in southern highbush blueberry. J. Amer. Soc. Hort. Sci. 126:386393.

Swain, P.A.W. and R.L. Darnell. 2002. Production systems influence source limitations to growth in 'Sharpblue' southern highbush blueberry. J. Amer. Soc. Hort. Sci. 127:409-414.

Williamson, J.G. and R.L. Darnell. 1996. Severity and timing of mechanical rejuvenation pruning affects vegetative and reproductive growth of blueberry. HortScience 31:663 (abstr.)

Williamson, J.G., F. Davies, and P.M. Lyrene. 2004. Pruning blueberry plants in Florida. University of Florida, Gainesville, FL. 6 June 2014. <http://edis.ifas.ufl.edu/hs223>.

Williamson, J.G. and E.P. Miller. 2002. Early and mid-fall defoliation reduces flower bud number and yield of southern highbush blueberry. HortTechnology 12:214-216.

Williamson, J.G. and P.M. Lyrene. 2004a. Blueberry varieties for Florida. University of Florida, Gainesville, FL. 6 June 2014. <http://edis.ifas. ufl.edu/pdffiles/HS/HS21500.pdf>.

Williamson, J.G. and P.M. Lyrene. 2004b. The Florida blueberry industry: A decade of growth. Proc. Fla. State Hort. Soc. 117:234 235.

Williamson, J.G., P.M. Lyrene, and J.W. Olmstead. 2012. Blueberry gardener's guide. University of Florida, Gainesville, FL. 6 June 2014. $<$ http://edis.ifas.ufl.edu/mg359>.

Williamson, J.G., J.W. Olmstead, G.K. England, and P.M. Lyrene. 2014. Southern highbush blueberry cultivars from the University of Florida. University of Florida, Gainesville FL. 7 July 2014. <http://edis.ifas.ufl.edu/hs1245>.

Wright, A.F. and P.F. Harmon. 2010. Identification of species in the Botryosphaeriaceae family causing stem blight on southern highbush blueberry in Florida. Plant Dis. 94:966971.

Yarborough, D.E. 2006. Blueberry pruning and pollination. In: Childers, N.F. (ed.). Blueberries for growers, gardeners, promoters. Horticultural Publications, Gainesville, FL. 